\title{
MAPPING AN URBAN CITY CENTRE FOR SEISMIC RISK ASSESSMENT: APPLICATION TO VALENCIA (SPAIN)
}

\author{
L. Basset-Salom ${ }^{1,2, *}$, A. Guardiola-Víllora ${ }^{1,2}$ \\ ${ }^{1}$ Dept. of Continuum Mechanics and Theory of Structures, Universitat Politècnica de València, Cno. Vera s/n, 46022 Valencia, \\ Spain, (lbasset, aguardio)@mes.upv.es \\ ${ }^{2}$ Research Centre PEGASO, Universitat Politècnica de València, Valencia, Spain
}

Commission II - WG II/8

KEY WORDS: Mapping, Buildings database, Heritage, Seismic risk, Seismic vulnerability

\begin{abstract}
:
Seismic risk in urban city centres may be high, even when the city is in low to moderate seismic areas, due to the vulnerability of the residential buildings. To assess the seismic vulnerability and estimate the expected damage in case of occurrence of an earthquake, an up-to-date detailed and comprehensive information of the residential building stock, such as number of dwellings, location, age, geometry, stiffness irregularities, structure, constructive system and practices, among others, is needed. This paper presents the authors experience, describing the step by step procedure followed to obtain the required information to classify and catalogue the residential buildings of the historical neighbourhoods of the city of Valencia into a database. Official sources, like the Cadastral Database, the website of the Urban Planning Service of the city of Valencia, the Municipal Historical Archive of Valencia, and the Historical Archive of the Valencian Architects Society, but also unexpected references are shared, pointing out the information that has been retrieved and its reliability. Additionally, relevant information must be obtained with an on-site data collection. This field work is essential not only to prove the accuracy of the abovementioned data but also to define some of the parameters related to the building vulnerability. The built database, included in a GIS system, has been used by the authors for seismic risk studies. This procedure can be implemented in future assessments at an urban scale.
\end{abstract}

\section{INTRODUCTION}

Urban city centres are, in general, characterized by a rich historic heritage, including not only monumental or religious buildings but also residential buildings varied in age and styles, with a majority of them made of unreinforced stone or brick masonry and, quite often, with bad level of maintenance.

The occurrence of recent earthquakes affecting urban city centres (L'Aquila, 2009, Lorca, 2011, Emilia Romagna, 2012, Katmandu, 2015, Amatrice, 2016, Bagan, 2016, etc.) has highlighted the need to assess the seismic risk, even in low to moderate seismic hazard countries in which less strong earthquakes can, nonetheless, cause severe damage, due to the high vulnerability of the buildings. The main reason is that many buildings don't meet the requirements to withstand seismic actions, neglecting, in addition, other factors which are relevant for an adequate seismic performance such as geometric or stiffness regularities (Basset-Salom et al., 2014).

There are different approaches to assess the seismic vulnerability of buildings (Calvi et al., 2006; Barbat et al., 2010; Novelli 2017), namely empirical methods such as the Damage Probability Matrix, DPM, (Whitman et al., 1973; Dolce et al., 2003) or the Vulnerability Index Methods, VIM, (Benedetti, Petrini, 1984; Giovinazzi, Lagomarsino, 2002; Milutinovich, Trendafiloski, 2003); analytical methods (D'Ayala, Speranza, 2002; Barbat et al., 2008; Irizarry et al., 2011; Lamego et al., 2017) and hybrid methods (Kappos et al., 1998; Maio et al,. 2016; Ferreira et al., 2017). The choice depends on the scale of the study, the resources for data collection or data availability and the required results (Guéguen et al 2007, Vicente et al. 2011, Chever 2012; Novelli 2017).
Regardless of the selected method, a detailed urban scale vulnerability assessment requires a thorough previous collection of accurate and comprehensive data of the residential building stock (such as location, age, geometry, stiffness irregularities, structure, constructive system and state of preservation, among others) which are usually stored in a database.

In this paper the step by step procedure (with application to the city of Valencia) is described, pointing out the information retrieved from the available sources and from the on-site survey, an irreplaceable key for data validation. These up-to-date data have been subsequently organised and stored in a georeferenced database included in a Geospatial Information System (GIS), which has been used for seismic risk assessment of some neighbourhoods in Valencia. This procedure can be implemented in future urban scale assessments.

\section{INFORMATION OF THE BUILDING STOCK FOR SEISMIC VULNERABILITY ASSESSMENT}

The type of required information of the residential buildings depends on the vulnerability assessment method.

The Risk-UE level 1 Vulnerability Index Method (Milutinovic, Trendafiloski, 2003), developed under the framework of the European research project Risk-UE (Mouroux et al., 2004) has been proved to be suitable for seismic vulnerability assessment of residential buildings in urban areas, where adequate estimates on the seismic intensity and building stock information are available. This method was successfully applied in the 7 European cities involved in the project (Barcelona, Bitola, Bucharest, Catania, Nice, Sofia and Thessaloniki) and has been

* Corresponding author 
used in the last 15 years in several studies carried out in Spain namely in Barcelona (Roca et al., 2006; Lantada, 2007; Lantada et al., 2010; Lantada et al., 2018), Gerona (Irizarry et al., 2012), Granada (Feriche, 2012), Lorca (Feriche et al., 2012; MartínezCuevas, Gaspar-Escribano, 2016; Rodenas et al., 2018), Valencia (Basset-Salom, Guardiola-Víllora, 2020) and VélezMálaga (Feriche et al., 2009), among others.

The seismic vulnerability of the building is defined with a vulnerability index, which accounts for the structural typology, construction materials and the specific features that might influence its seismic performance, implemented by means of regional or behaviour modifiers.

To characterise the residential buildings for seismic vulnerability assessment with the abovementioned method, the following information related to the building itself and to its location within the block is needed: age, structural typology, geometrical configuration, stiffness irregularities, state of preservation, aggregate building position and existing antiseismic or strengthening devices.

- The age of the building is essential because it helps defining the construction system and the quality of the materials, based on the constructive recommendations, the codes in force at that moment and the particularities in the region.

- The structural typology of the building is defined according to the Building Typology Matrix (Table 1) proposed by Risk-UE (Milutinovic, Trendafiloski, 2003), which classifies structures with a similar ability to withstand seismic loads. Adequate values of the vulnerability indices are assigned to each structural typology within the frame of the fuzzy set theory (Giovinazzi, Lagomarsino, 2002), indicating its membership to one of the six EMS 98 vulnerability classes (Grüntal, 1998): from A (highest vulnerability) to F (lowest vulnerability).

- The geometrical configuration influences the vulnerability of the buildings. The number of storeys, area, perimeter and volume of the building must be obtained to define the geometric irregularities, both in plan (horizontal irregularity) and elevation (vertical irregularity). The difference in height between adjacent buildings, when greater than, or equal to, two storeys (see Figure 1) must be included too because, in this case, the risk of pounding effects is not negligible.

- The existence of a soft storey and/or short columns must be recorded. These stiffness irregularities have proved to be relevant in the seismic response of buildings, as shown in the pictures of Figure 2, corresponding to the effects of Lorca 11th May 2011 earthquake.

- Despite the influence of the construction techniques, the state of preservation is a determinant factor in the buildings seismic performance, especially in the case of unreinforced masonry (URM) buildings, not only for the building itself, but also due to the lack of the stabilizing contribution of neighbouring cells when the maintenance level is bad or the building is ruined (Carocci, Lagomarsino, 2009; Basset-Salom, Guardiola-Víllora, 2013; Guardiola-Víllora, Basset-Salom, 2019). Figure 3 shows buildings of the same typology but with different state of preservation.

\begin{tabular}{|c|c|c|}
\hline \multicolumn{2}{|c|}{$\begin{array}{l}\text { BUILDING } \\
\text { TYPOLOGY }\end{array}$} & DEFINITION \\
\hline \multirow{10}{*}{ Masonry } & M1.1 & Rubble stone masonry bearing walls \\
\hline & M1.2 & Simple stone masonry bearing walls \\
\hline & M1.3 & Massive stone masonry bearing walls \\
\hline & M2 & Adobe \\
\hline & M3.1 & $\begin{array}{l}\text { Unreinforced masonry (URM) bearing } \\
\text { walls with wooden slabs }\end{array}$ \\
\hline & M3.2 & $\begin{array}{l}\text { Unreinforced masonry (URM) bearing } \\
\text { walls with masonry vaults }\end{array}$ \\
\hline & M3.3 & $\begin{array}{l}\text { Unreinforced masonry (URM) bearing } \\
\text { walls with composite steel and } \\
\text { masonry slabs }\end{array}$ \\
\hline & M3.4 & $\begin{array}{l}\text { Bearing walls with reinforced concrete } \\
\text { slabs }\end{array}$ \\
\hline & M4 & $\begin{array}{l}\text { Reinforced or confined masonry } \\
\text { bearing walls }\end{array}$ \\
\hline & M5 & $\begin{array}{lll}\begin{array}{l}\text { Overall } \\
\text { buildings }\end{array} & \text { strengthened } & \text { masonry } \\
\end{array}$ \\
\hline \multirow{7}{*}{ Concrete } & $\mathrm{RC1}$ & Concrete moment frames \\
\hline & $\mathrm{RC} 2$ & Concrete shear walls \\
\hline & RC 3.1 & $\begin{array}{l}\text { Concrete frames with regular } \\
\text { unreinforced masonry infill walls }\end{array}$ \\
\hline & $\mathrm{RC} 3.2$ & $\begin{array}{l}\text { Irregular concrete frames with } \\
\text { unreinforced masonry infill walls }\end{array}$ \\
\hline & $\mathrm{RC} 4$ & $\mathrm{RC}$ dual systems (RC frame and wall) \\
\hline & RC5 & Precast concrete walls \\
\hline & RC6 & $\begin{array}{l}\text { Precast concrete frames, concrete shear } \\
\text { walls }\end{array}$ \\
\hline \multirow{5}{*}{ Steel } & S1 & Steel moment frames \\
\hline & S2 & Steel braced frames \\
\hline & S3 & $\begin{array}{l}\text { Steel frames with unreinforced } \\
\text { masonry infill walls }\end{array}$ \\
\hline & S4 & $\begin{array}{l}\text { Steel frames with cast in place } \\
\text { concrete shear walls }\end{array}$ \\
\hline & S5 & $\begin{array}{l}\text { Steel and reinforced } \\
\text { composite systems }\end{array}$ \\
\hline Wood & $\mathrm{W}$ & Wood structures \\
\hline
\end{tabular}

Table 1. Building Typology Matrix proposed by Risk-UE (Milutinovic and Trendafiloski 2003).

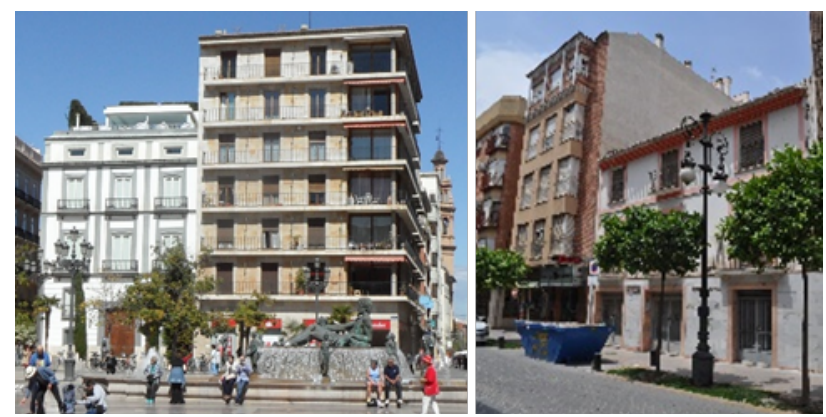

Figure 1. Differences in height (credit: the authors).

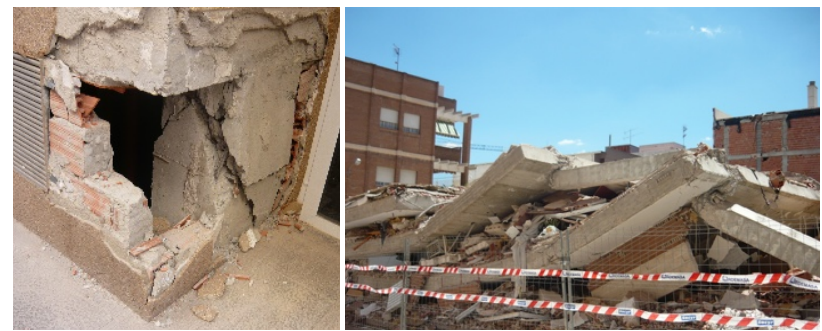

Figure 2. Buildings with short columns after Lorca 11th May 2011 earthquake (credit: the authors). 
- The aggregate building position (relative position of the building in plan with respect to the rest of the buildings in the same block) is a factor which affects directly the seismic vulnerability. Three locations are considered: middle, corner and header (Figure $4 a, 4 b$ and $4 c$ ), being the header position the worse one in terms of the building seismic response. When a building is adjacent to a longterm empty plot (Figure 4d) it has to be considered as a corner or header building.

- Finally, information about any existing anti-seismic device in the building (such as quoins, ring beams, ties, etc) must be collected. These devices have been proved to be effective in masonry buildings in Lorca during the 11th May 2011 earthquake (Guardiola-Víllora, Basset-Salom, 2014).
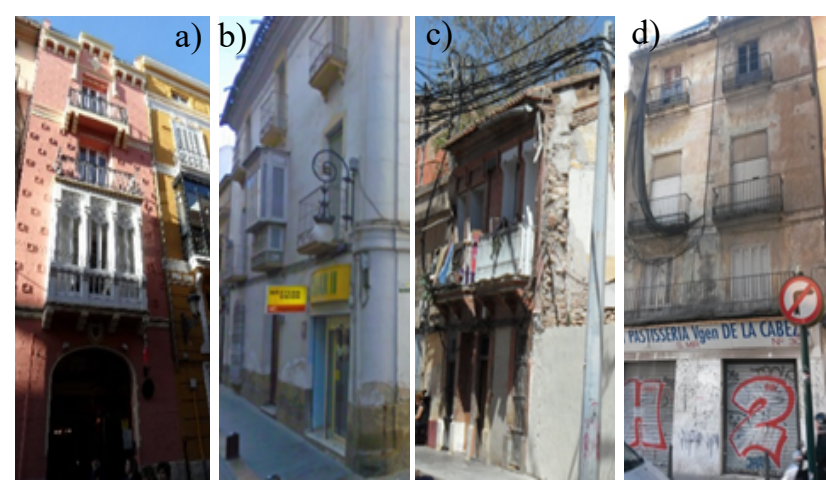

Figure 3. State of preservation: a) good, b) medium, c) bad, d) ruined and unoccupied (credit: the authors).
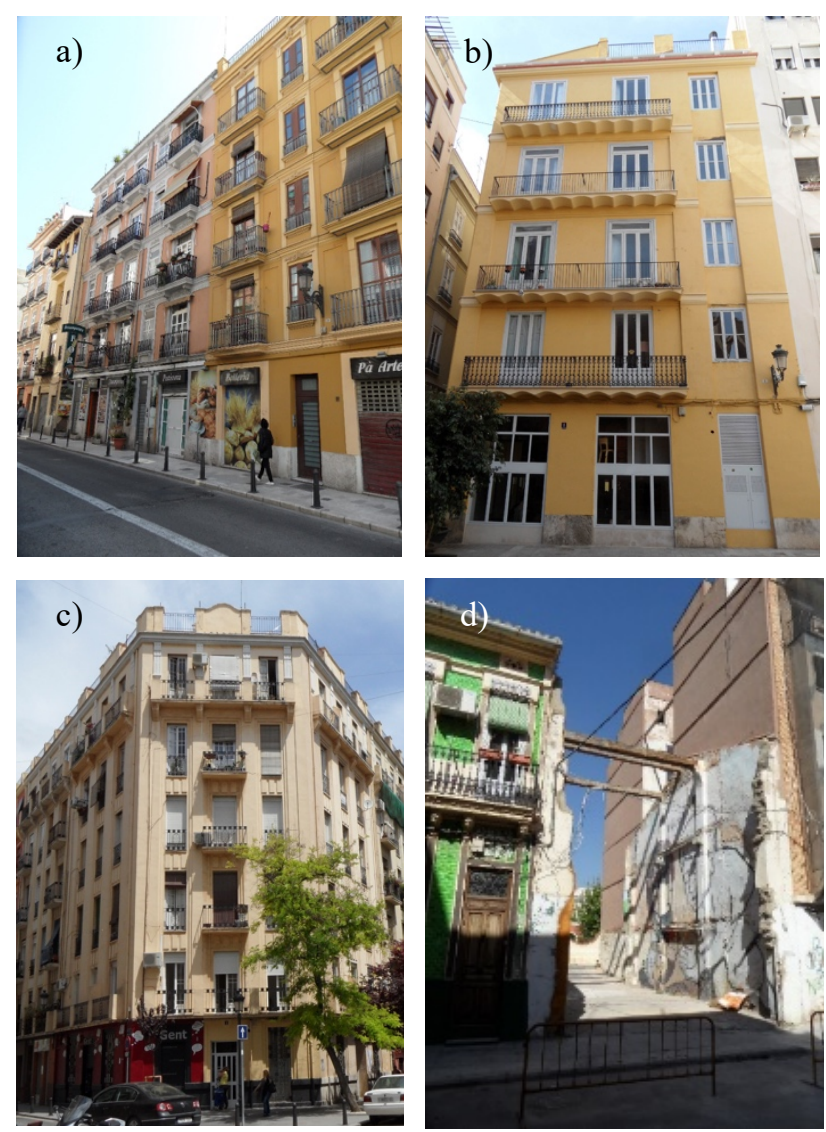

Figure 4. Aggregate building position; a) middle, b) corner, c) header, d) adjacent to a long-term empty plot (credit: the authors).

\section{BUILDING THE DATABASE FOR SEISMIC RISK ASSESSMENT}

The process of building the database for seismic risk assessment can be structured in 3 stages: preliminary office work; data collection and, finally, data processing and mapping.

\subsection{Preliminary office work}

The preliminary office work consists in preparing the skeleton of the georeferenced database (DB) of the building stock of the urban area under study.

Each record should correspond to a building, identified by the block and the plot number and its geographical coordinates. To link this information with the geographical coordinates, the DB is built from the Spanish Cadastral Database (SEC, 2020), allowing a complete geometrical and geographical characterization of the building stock.

An example of how the information is given in the cadastral database is shown in Figure 5.

When data are extracted from the Cadastral Database, many records (rows), each one related to a different construction part of the same building, are identified with the same reference number (Refcat), corresponding to the same block (masa) and plot (parcela), as can be seen in the table of Figure 5.
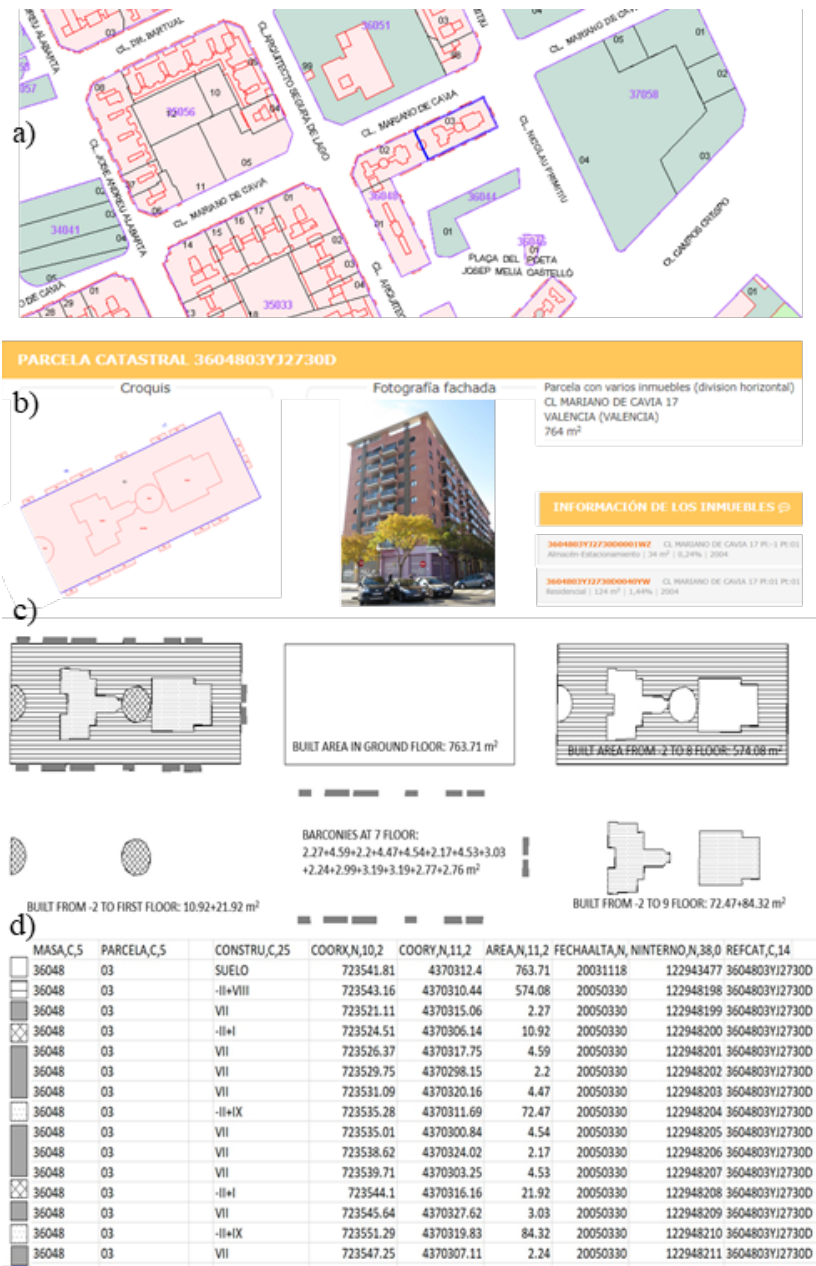

Figure 5. Cadastral Database: a) cadastral map, b) building plan, c) shapes corresponding to each construction part of the same building, d) records (SEC, 2020). 
In this Figure, each construction part is identified according to its shape, the number of storeys involved and the geographical coordinates. For example, the properties of the white rectangle at the ground floor are represented in the first row. The shapes in striped, diagonal square grid, dotted, and solid patterns correspond, respectively, to the rows in the table with the same labels on the left.

To check which area corresponds to each row, there is a measuring tool in the Cadastral Database viewer, allowing areas and lengths to be measured (Figure 6).

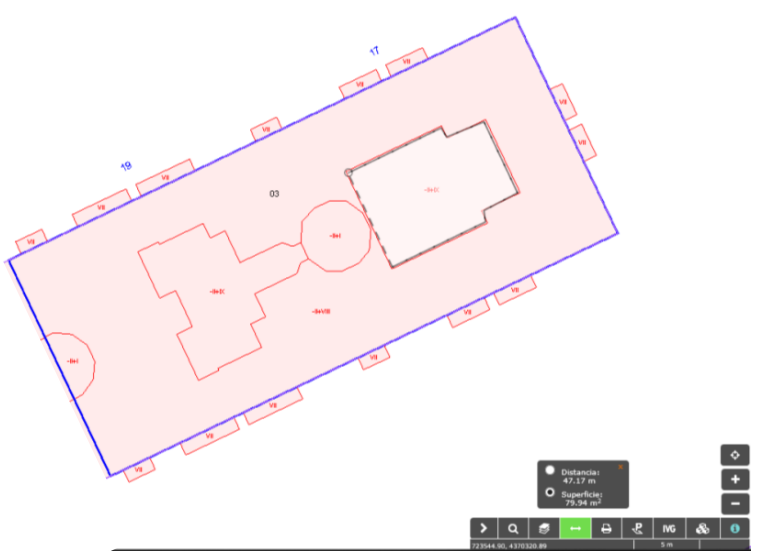

Figure 6. Measuring tool in the Cadastral Database (SEC, 2020).

All the records corresponding to the same building (with the same block, plot and reference number) are condensed into a single record and transferred to the DB (still under construction at this stage) for the seismic risk assessment. The total built area of the building is calculated by adding the area of each part.

Subsequently, for each record (each building), the following information is obtained from the Cadastral Database: all the geometrical dimensions (plot area, perimeter at ground floor, façade length, building dimensions at each storey, etc), the total built area, the number of storeys, the main occupancy use and the age. The age of the building included in the Cadastral Database corresponds to the year of construction or, sometimes, to the year of the last retrofitting intervention in the building, even in the case of a non-structural intervention. This is one of the reasons why the age of the building must be validated with the field survey and/or with the original project when available.

\subsection{Data collection. Application to Valencia}

The purpose of the data collection is to validate, complete and enhance the information retrieved from the Cadastral Database, adding structural system description, construction details and the state of preservation, essential to evaluate the building seismic response.

Normally these data are obtained from regional or local sources where the city urban plans or the architectural projects can be consulted.

This part of the paper refers to the available and reliable sources in Valencia such as the Urban Planning Service or institutions like the Municipal Historical Archive of Valencia or the Architectural Information Centre of the School of Architecture of Valencia, among others. It should be pointed out that there are similar sources in other cities.

Finally, it is always highly recommended to carried out an onsite data collection.
3.2.1 Urban Planning Service of the City of Valencia: The Urban Planning Service of the City of Valencia can be accessed on-line through the City Council geoportal (https://geoportal.valencia.es/home/), which provides on-line city maps and detailed urban information of the buildings (Figure 7) or through the City Council website (https://www.valencia.es/ayuntamiento/urbanismo.nsf) where the documents of the urban plans can be downloaded.

Several Special Protection Plans have been drafted, having as scope of action a district of the city of Valencia. In general, these plans are intended to promote the renovation, rehabilitation and reconstruction of the residential buildings, the conservation of the heritage buildings, the creation of services (social, cultural and educational), the regeneration of public spaces and the revitalisation of the corresponding district.

This is the case of the Special Protection Plans of L'Eixample district (approved in 2005 and 2006 respectively), the Special Protection Plan of Ciutat Vella (provisionally approved in 2019) or the Special Protection Plan of El Cabanyal (in process of approval).

The documents included in these plans (catalogue of listed buildings, reports and maps) provide information of the protection grades, the state of the building, the property status, the number of storeys, the age, etc. However, the information about the structural system is, sometimes, not as accurate as needed.

An example of a database record of the catalogue and of the state of preservation map of the preliminary version of the Special Protection Plan of Ciutat Vella are shown, respectively, in Figures 8 and 9.

3.2.2 Institutional sources: The original (or rehabilitation) project of the residential buildings can be found in some institutional sources such as the Municipal Historical Archive of Valencia (MHAV), the Architectural Information Centre of the Architecture School in Valencia (CIA-ETSA), the institutional repository of the Universitat Politècnica de Valencia (UPVRiunet) or the Historical Archive of the Valencian Architects Society.

Normally the documents of these architectural projects contain the year in which they were drafted, the name of the architect, the distribution plans, the elevations, a section, a brief description of the structure in the constructive report or in the budget and, sometimes, depending on the date, several structural plans and other constructive details.

The MHAV has no digitalized version, at the moment, of the stored projects, which must be consulted on-site, but it is the only place where projects dating from the 18 th century can be found.

The CIA-ETSA has digitalized and non-digitalized documents from several private donations such as the Rieta collection ${ }^{1}$. The digitalized versions can be accessed on-line at the UPV-Riunet.

Examples of documents retrieved from the MHAV, the CIAETSA and the UPV-Riunet, are shown in Figure 10, Figure 11 and Figure 12, respectively.

This collection contains the original projects of the Valencian
architect Joaquín Rieta Sister, donated by his family to the CIAETSA. 


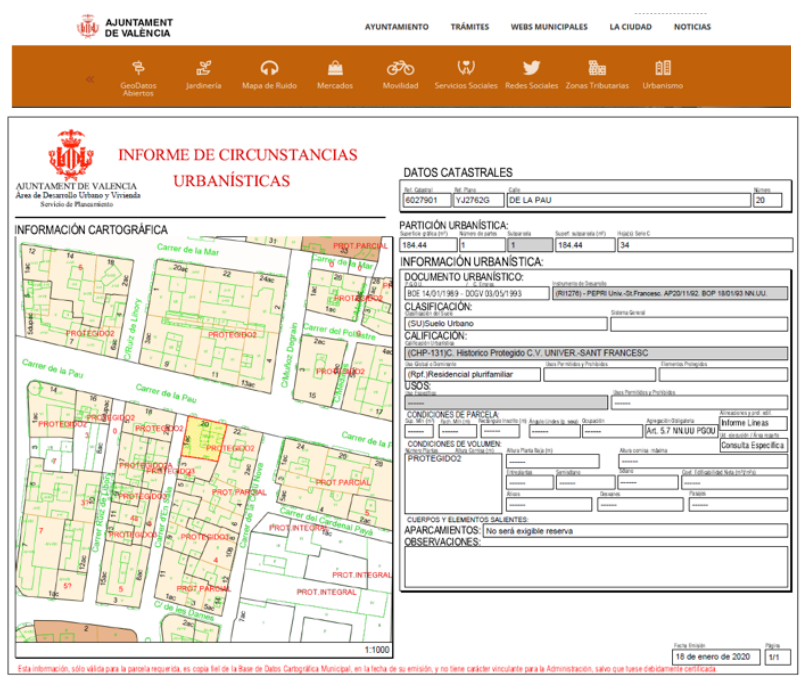

Figure 7. Urban information of a building provided by the Urban Planning Service on the Valencia City Council.

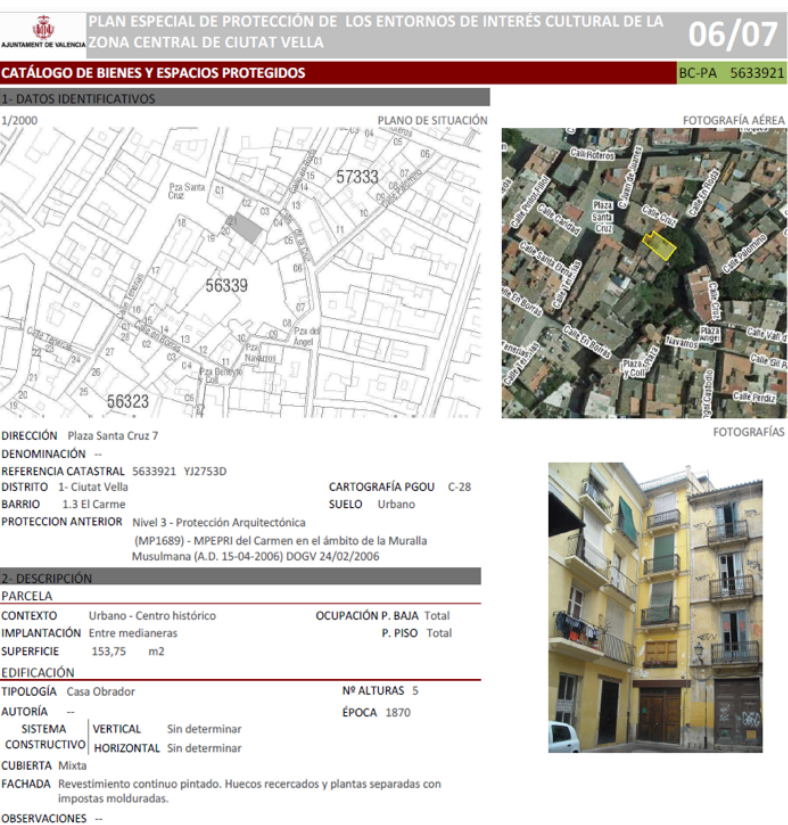

Figure 8. Record file of a building included in the Catalogue of listed buildings of the Special Protection Plan of Ciutat Vella (Source: Ayuntamiento de Valencia).

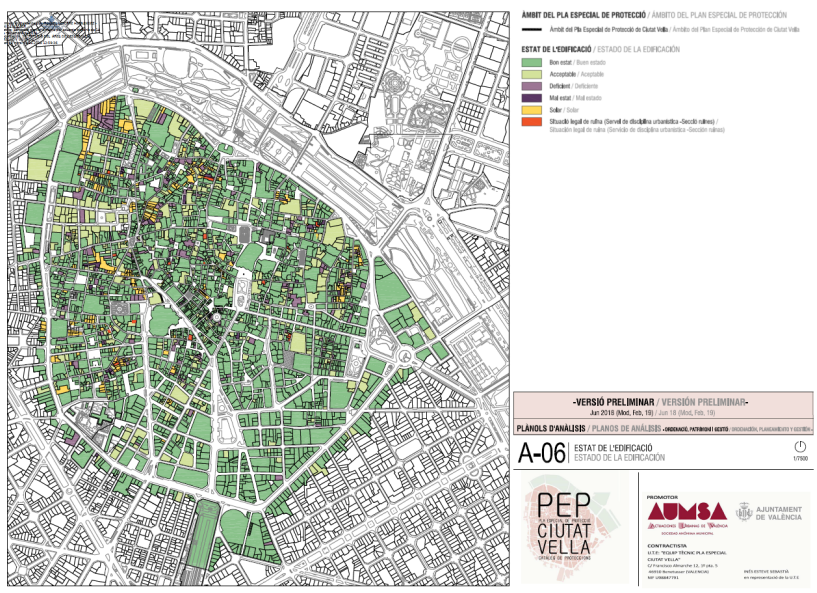

Figure 9. Special Protection Plan of Ciutat Vella: State of preservation map. (Source: Ayuntamiento Valencia).
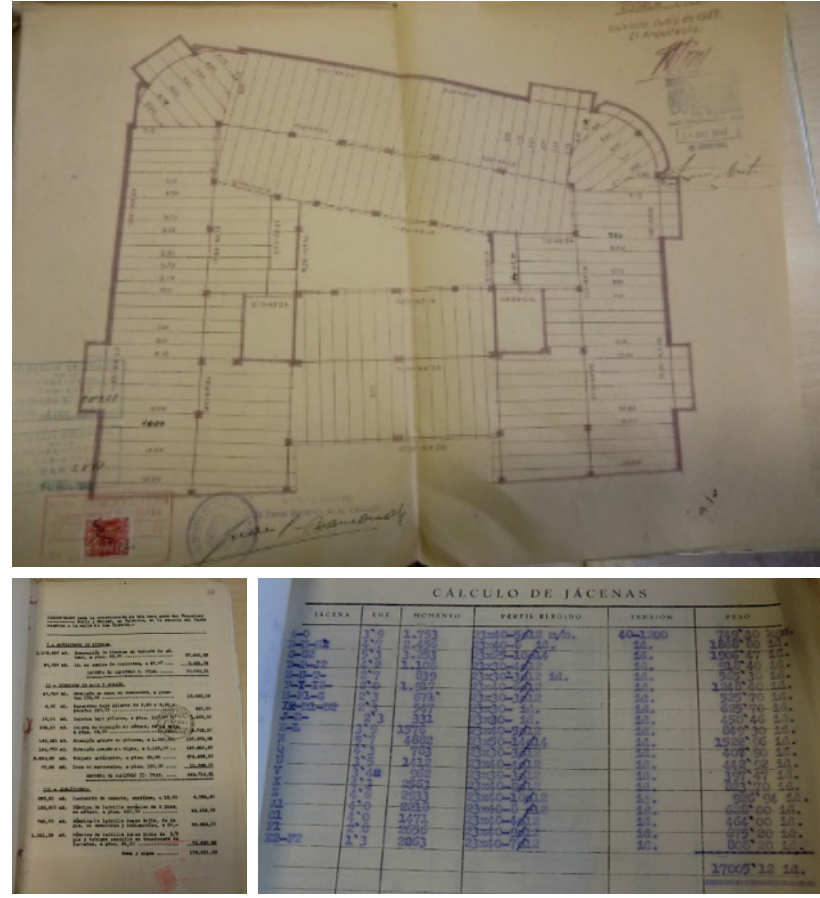

Figure 10. Example of a structure plan, budget and constructive report (Source: MHAV).

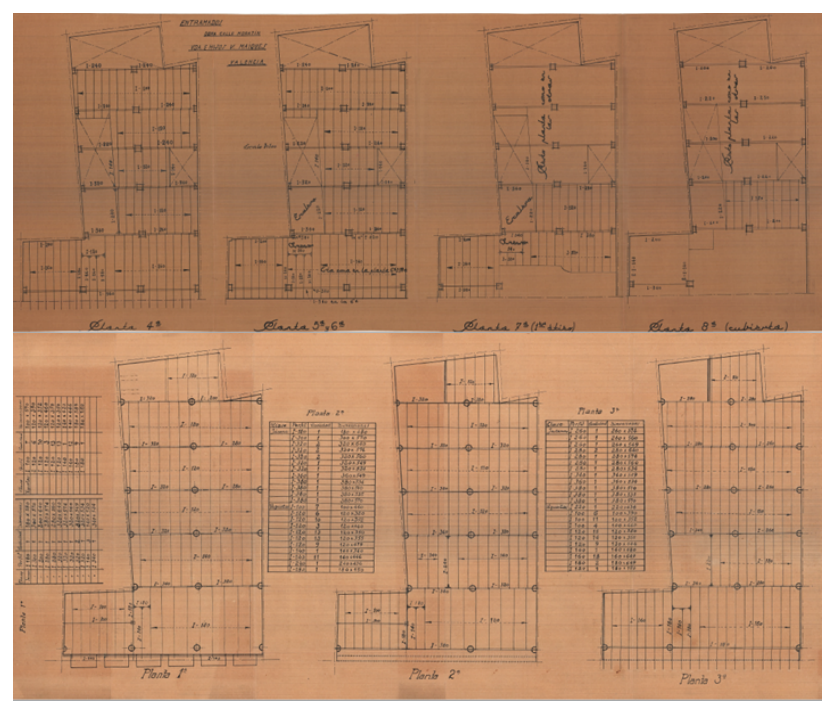

Figure 11. Structure plans, Moratin Street no. 3 (Source: Rieta Sister, 1941, Rieta Collection, CIA-ETSA).

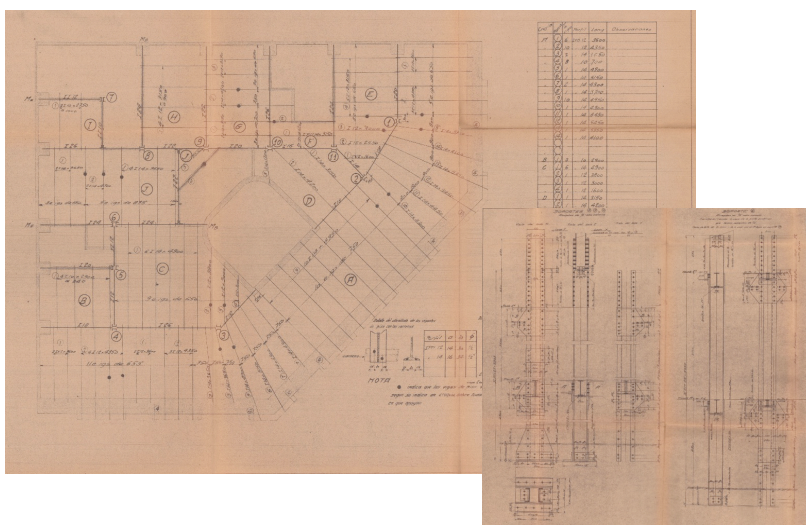

Figure 12. Structure plans, Gran Via Marqués del Turia Avenue, (Source: Rieta Sister, 1929, UPV- Riunet). 
3.2.3 Other sources: Structural information of the residential building stock in Valencia can also be found, but only in very specific cases, in other reliable sources, such as the Valencia's Architecture Guide (Figure 13) of the Valencian Architects Society (CTAV).

The Iberian DOCOMOMO focuses on the architectural heritage of the Modern Movement. The Register includes an inventory of the Spanish Twentieth Century Architecture. The building in Figure 14 'Edificio Alfonso' is included in this Register.

Other less common sources are final Degree Theses, Master Theses, PhD Theses, research papers, architecture websites or blogs (see photo of the construction process of a building in Figure 15).
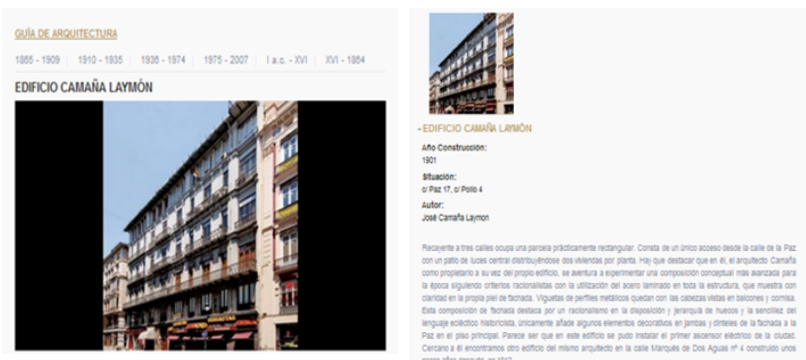

Figure 13. Building Camaña Laymon at La Paz Street. (Source: Valencia's Architecture Guide, CTAV).

\section{EDIFICIO ALONSO}

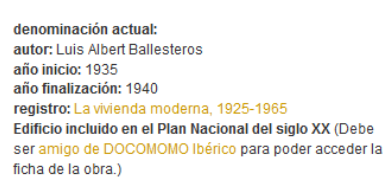

ficha de la obra.)
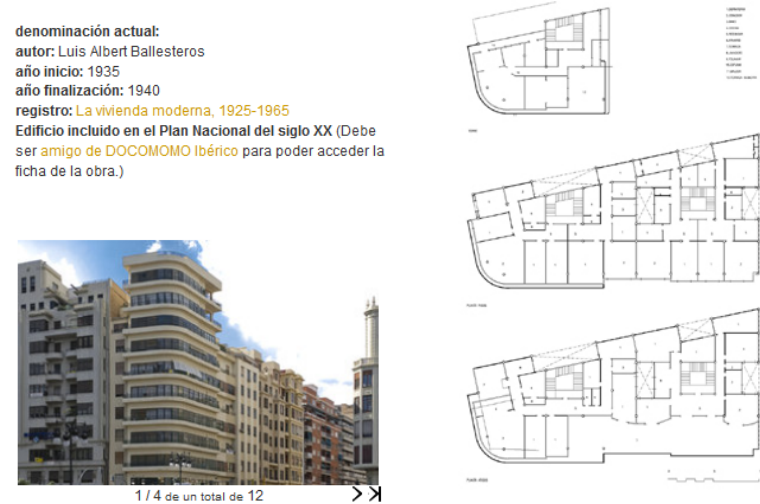

Figure 14. Building Alonso at S. Vicente Street. (Source: Iberian DOCOMOMO Register and MHAV).

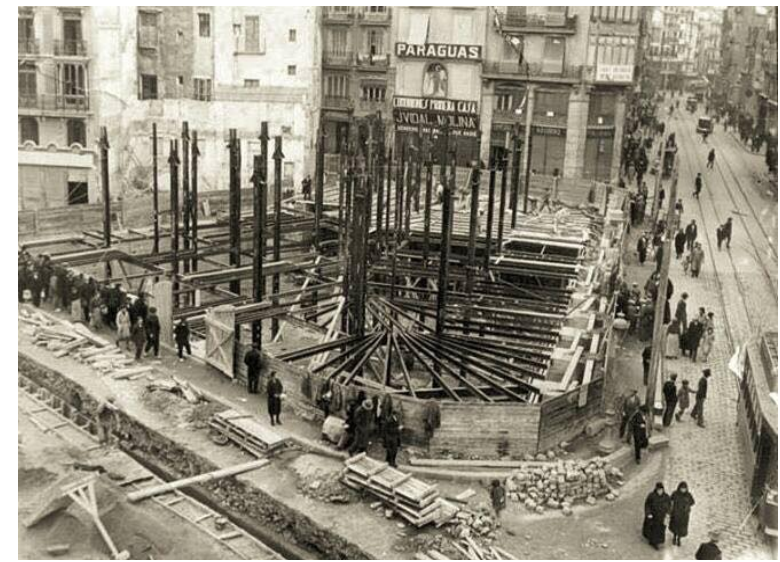

Figure 15. Building at 16 San Vicente Street, 1921-1931. Arch: F. Almenar \& J Goerlich (Source: Fundación Goerlich).
3.2.4 On-site survey: Once the information retrieval process from the different sources is finished and all the records have been transferred to the preliminary database, it is essential to carry out an exhaustive on-site data collection to validate and complete the retrieved information, especially age, number of storeys, structural typology, constructive system, stiffness irregularities (short column, soft storey), geometry, state of preservation and possible retrofitting interventions. Sometimes the abovementioned data are only obtained in these visits.

It is also recommended to take a set of georeferenced pictures of each building (identifying block and plot), including, if possible, structural and constructive details. An example of different structural typologies of the residential buildings in Valencia is shown in Figure 16. These pictures are stored in a complementary graphical database. Pictures can also be taken from Street view or, recently, from the Cadastral Database.
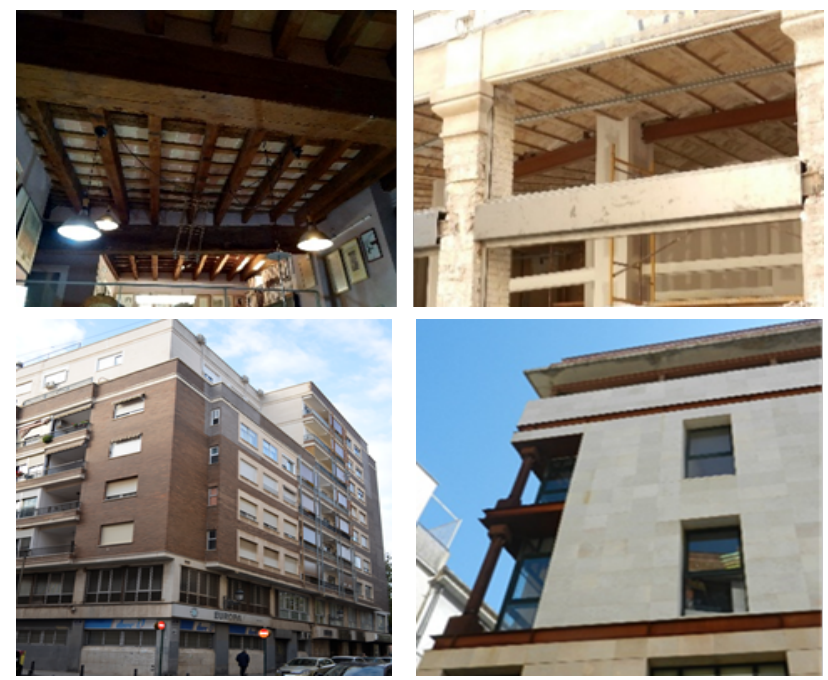

Figure 16. Example of structural typologies in Valencia: URM timber beams and joists; URM steel beams and joists, Reinforce concrete and Steel structures (credit: the authors).

\subsection{Data processing and mapping}

All the collected data (including cadastral, graphical, geometrical, typological, structural, constructive and maintenance information) are stored and organised in the residential building DB for seismic risk assessment, connected to a Geographical Information System (gvSIG association 2009) to identify each building within the urban context.

These data are then processed for implementation in the corresponding vulnerability assessment method. In the case of the Risk-UE level 1 Vulnerability Index Method, they are used, firstly, to define the representative value of the vulnerability indices according to each structural typology and, secondly, to determine the regional and behaviour modifiers which depend on the specific characteristics of each building. The vulnerability indices are then calculated, and the buildings classified into one of the six vulnerability classes mentioned in section 2. Subsequently, their expected damage is estimated for each seismic hazard scenario and the seismic risk assessed in terms of direct social and economic losses. Results are mapped using the GIS system tool showing the distribution of the vulnerability indices and the expected damage for the considered seismic hazard scenarios. As an example, Figure 17 shows the map of the vulnerability indices in L'Eixample, Valencia (GuardiolaVíllora A, Basset-Salom L, 2015). 


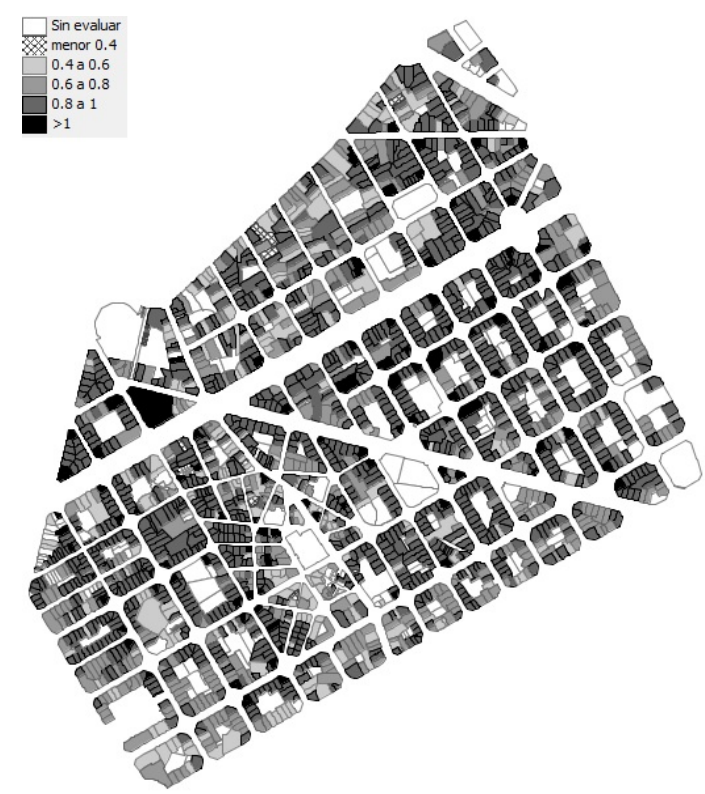

Figure 17. Map of Vulnerability Indices in L'Eixample district Valencia (Guardiola-Víllora A, Basset-Salom L, 2015).

\section{CONCLUSIONS}

In this paper the procedure to map an urban area for seismic risk assessment has been explained and the process to build a comprehensive, reliable and georeferenced building database in a city with the history and scale of Valencia has been described.

To estimate adequately the seismic vulnerability of residential buildings, information related to the main factors influencing their seismic performance should be available to define the most suitable vulnerability indices.

The geometrical configuration (number of storeys, dimensions, horizontal and vertical irregularities, etc) and age, obtained from the Cadastral Database (SEC, 2020), must be completed with information concerning the structural system, materials and construction techniques, as well as the state of preservation. There are different reliable sources from which these data can be retrieved. The sources mentioned in the paper are applicable to the city of Valencia, however, similar sources can be found in other Spanish regions, so this process can be implemented in similar urban scale assessments.

Based on the authors' experience, an on-site data collection is imperative, not only to validate the information contained in these sources (which in many cases is not entirely accurate), but also to complete it.

The development of a georeferenced building DB is essential to perform a seismic vulnerability assessment. Furthermore, the applicability of this DB is broader, since it can be completed with additional data required not only to develop all types of emergency plans or to forecast the effects of the climate change in the city but also for different studies such as the evaluation of the energy sustainability of the built stock or the design of reversible construction projects in which repair, reuse and efficient recovery of materials and components leading to waste reduction are the main objectives.

Finally, it is worth pointing out that the information depicted in the maps is static and reflects the situation at a given time. The database must be alive and in a continuous updating process.

\section{ACKNOWLEDGEMENTS}

This paper is related with the research project "RISK-Terra. Earthen architecture in the Iberian Peninsula: study of natural, social and anthropic risks and strategies to improve resilience" (RTI2018-095302-B-I00), funded by the Spanish Ministry of Science, Innovation and Universities.

\section{REFERENCES}

Barbat, A.H., Carreño, M.L., Pujades, L.G., Lantada, N., Cardona, O.D., Marulanda, M.C., 2010. Seismic vulnerability and risk evaluation methods for urban areas. A review with application to pilot area. Structure and Infrastructure Engineering, 6, 17-38.

Barbat, A.H., Pujades, L. G, Lantada, N., 2008. Seismic damage evaluation in urban areas using a capacity-spectrum based method: Application to Barcelona. Soil Dynamics and Earthquake Engineering, 28(10-11), 851-865

Basset-Salom, L., Guardiola-Víllora, A., 2013. Influence of the maintenance in seismic response of Lorca historic centre masonry residential buildings after 11 May Earthquake. Studies, Repairs and Maintenance of Heritage Architecture XIII. WIT Transactions on the Built Environment, 131, 343-354.

Basset-Salom, L., Guardiola-Víllora, A., 2014. Seismic performance of masonry residential buildings in Lorca's city centre, after the $11^{\text {th }}$ May 2011 earthquake. Bull. Earthquake Eng., 12, 2027-2048.

Basset-Salom, L., Guardiola-Víllora, A., 2020. Seismic vulnerability and expected damage in "Ground Zero Area" in El Cabanyal (Valencia). Int. Journal of Architectural Heritage. DOI 10.1080/15583058.2019.1710783

Benedetti, D., Petrini, V., 1984. Sulla Vulnerabilità di Edifici in Muratura: Proposta di un Metodo di Valutazione. L'industria delle Costruzioni, 149(1), 66-74.

Calvi, G.M., Pinho, R., Magenes, G., Bommer, J.J., RestrepoVélez, L.F., Crowley, H., 2006. Development of seismic vulnerability assessment methodologies over the past 30 years. ISET Journal of Earthquake Technology, 43(3),75-104.

Carocci, C.F. Lagomarsino, S., 2009. Gli edifici in muratura nei centri storici dell' Aquilano. Progettazione Sismica 3, 117-134.

Chever, L., 2012. Use of seismic assessment methods for planning vulnerability reduction of existing building stock. $15^{\text {th }}$ World Conference on Earthquake Engineering, Lisbon, Portugal, September 24-28, 2012.

D’Ayala, D., Speranza, E., 2002. An Integrated Procedure for the Assessment of Seismic Vulnerability of Historic Buildings, Proceedings of the 12th European Conference on Earthquake Engineering, London, U.K., paper 561

Dolce, M., Masi, A., Marino, M. and Vona, M., 2003. Earthquake Damage Scenarios of the Building Stock of Potenza (Southern Italy) Including Site Effects", Bull. Earthquake Eng., 1(1), 115-140.

Feriche, M., 2012. Elaboración de escenarios de daños sísmicos en la ciudad de Granada. PhD Thesis. Inst. andaluz de Geofísica y prevención de Desastres sísmicos. Universidad de Granada. 
Feriche, M., Vidal, F., Alguacil, G., Navarro, M., Aranda, C., 2012. Vulnerabilidad y daño en el terremoto de Lorca de 2011, $7^{a}$ Asamblea Hispanoportuguesa de Geodesia y Geofisica, San Sebastián, España, 25-28 junio 2012.

Feriche, M., Vidal, F., García, R., Navarro, M, Vidal ,M. D., Montilla, P., Piñero, L., 2009. Earthquake Damage Scenarios in Vélez- Málaga urban area (Southern Spain) applicable to Local Emergency Planning. $8^{\text {th }}$ Int. Workshop on Seismic Microzoning and Risk Reduction, Almería, Spain, 15-18 March 2009.

Ferreira, T.M., Maio, R., Vicente, R., 2017. Seismic vulnerability assessment of the old city centre of Horta, Azores: calibration and application of a seismic vulnerability index method. Bull. Earthquake Eng., 15, 2879-2899.

Giovinazzi, S, Lagomarsino, S., 2002. WP04: Guidelines for the implementation of the 1 level methodology for the vulnerability assessment of current buildings: RISK-UE project. University of Genoa (Italy).

Grünthal G., 1998. European Macroseismic Scale 1998. Cahiers du Centre Européen de Géodynamique et de Séismologie, 15.

Guardiola-Víllora, A, Basset-Salom, L, 2014. Seismic Risk mitigation of Lorca historic centre masonry residential buildings, in Spain. Vernacular Heritage and Earthen Architecture: Contributions for Sustainable Development, 689694. Ed. Taylor \& Francis, London. ISBN 978-1-138-00083-4.

Guardiola-Víllora, A, Basset-Salom, L, 2015. Escenarios de riesgo sísmico del distrito del Eixample de la ciudad de Valencia. Revista Internacional de Métodos Numéricos para el Cálculo y Diseño en Ingeniería, 31(2), 81-90.

Guardiola-Víllora, A, Basset-Salom, L., 2019. Earthquake risk scenarios of the Ciutat Vella District in Valencia, Spain. Bull. Earthquake Eng. DOI: doi.org/10.1007/s10518-019-00745-7

Guéguen, Ph, Michel, C., LeCorre, L., 2007. A simplified approach for vulnerability assessment in moderate-to-low seismic hazard regions: application to Grenoble (France). Bull. E

gvSIG association, 2009. gvSIG Desktop, the Open Source Geographic Information System.

http://www.gvsig.com/en/home (18 November 2019)

Irizarry, J., Lantada, N., Pujades, L.G., Barbat, A.H., Goula, X., Susagna, T., Roca, A., 2011. Ground-shaking scenarios and urban risk evaluation of Barcelona using the Risk-UE capacity spectrum-based method. Bull. Earthquake Eng., 9(2), 441-466.

Irizarry, J., Macau, A., Figueras, S., Goula, X., Lantada, N., Vendrell, S., Pujades, L.G., Blázquez, A., 2012. Seismic risk assessment for the city of Girona, Spain. $15^{\text {th }}$ World Conference on Earthquake Eng. Lisbon, Portugal, September 24-28, 2012.

Kappos, A.J., Stylianidis, K.C., Pitilakis, K., 1998. Development of seismic risk scenarios based on hybrid method of vulnerability assessment. Natural Hazards, 17(2), 177-192.

Lamego, P., Lourenço, P.B., Sousa, M.L., Rui Marques, R., 2017. Seismic vulnerability and risk analysis of the old building stock at urban scale: application to a neighbourhood in Lisbon. Bull. Earthquake Eng., 15, 2901-2937.

Lantada, N., 2007. Evaluación del riesgo sísmico mediante métodos avanzados y técnicas GIS. Aplicación a la ciudad de Barcelona. PhD Thesis. U.P. Cataluña, Barcelona.
Lantada, N., Irizarry, J., Barbat, A., Goula, X., Roca, A., Susagna, T., Pujades, L.G., 2010. Seismic hazard and risk scenarios for Barcelona, Spain, using the Risk-UE vulnerability index method. Bull. Earthquake Eng. 8(2), 201-229.

Lantada, N., Pujades, L.G., Barbat, A.H., 2018. Earthquake Risk Scenarios in Urban Areas: A Review with Applications to the Ciutat Vella District in Barcelona, Spain. International Journal of Architectural Heritage, 12(7-8), 1112-1130.

Maio, R., Ferreira, T.M., Vicente, R., and Estêvão, J., 2016. Seismic vulnerability assessment of historical urban centres: case study of the old city centre of Faro, Portugal. Journal of Risk Research, 19(5), 551-580.

Martínez-Cuevas, S., Benito, M.B., Cervera, J., Morillo, M.C, Luna, M., 2017. Urban modifiers of seismic vulnerability aimed at Urban Zoning Regulations. Bull. Earthquake Eng., 15, 47194750

Milutinovic, Z.V., Trendafiloski, G.S., 2003 WP04. Vulnerability of current buildings. RISK-UE project: an advanced approach to earthquake risk scenarios with applications to different European towns. Inst. of Earthquake Engineering and Engineering Seismology (IZIIS), Skopje.

Mouroux, P., Bertrand, E., Bour, M, Le Brun, B., Depinois, S., Masure Ph., 2004. The European RISK-UE Project: An advanced approach to earthquake risk scenarios, in: Proc. of the 13th World Conference on Earthquake Engineering (13 WCEE), Vancouver, BC, Canada, 1-6 August, paper 3329.

Novelli, V.I., 2017. Hybrid method for the seismic vulnerability assessment of historic masonry city centres. Ph.D. Thesis. University College London.

Rieta Sister, J., 1929. Entramado metálico de la Compañía Siderúrgica del Mediterráneo para el Edificio de viviendas de D. Portaceli en Avenida Gran Vía Marqués del Turia de Valencia, 1929. http://hdl.handle.net/10251/77816 (18 November 2019)

Rieta Sister, J., 1941. Proyecto de construcción de edificio en Calle Moratín 3 de Valencia para familia Maiques, 1941. http://hdl.handle.net/10251/118747 (18 November 2019)

Roca, A., Irizarry, J., Lantada, N., Barbat, A., Goula, X., Pujades, L.I., Susagna, T., 2006. Método Avanzado para la Evaluación de la Vulnerabilidad y el Riesgo Sísmico. Aplicación a la Ciudad de Barcelona. Física de la Tierra, 18, 183-203.

Ródenas, J. L., Tomás, A, García-Ayllón, S., 2018. Advances in seismic vulnerability assessment of reinforced concrete buildings applied to the experience of Lorca (Spain) 2011 earthquake. Int. J. Comp. Meth. and Exp. Meas, 6(5),887-898.

SEC, 2020. Sede Electrónica del Catastro. Ministerio de Hacienda. Gobierno de España. https://www.sedecatastro.gob.es (12 December 2019)

Vicente, R., Parodi, S., Lagomarsino, S.,'Varum, H.,'Mendes Silva, J. A. R., 2011. Seismic vulnerability and risk assessment: case study of the historic city centre of Coimbra, Portugal. Bull. Earthquake Eng. 9(4),1067-1096.

Whitman R.V., Reed J.W. Hong, S.T., 1973. Earthquake Damage Probability Matrices. Proceedings of the $5^{\text {th }}$ World Conference on Earthquake Engineering, Rome, Italy, 2, 25312540. 